This item was submitted to Loughborough's Research Repository by the author.

Items in Figshare are protected by copyright, with all rights reserved, unless otherwise indicated.

\title{
A level playing field: social inclusion in public leisure
}

PLEASE CITE THE PUBLISHED VERSION

http://dx.doi.org/10.1108/09513551211200285

PUBLISHER

(c) Emerald Group Publishing Limited

VERSION

AM (Accepted Manuscript)

LICENCE

CC BY-NC-ND 4.0

REPOSITORY RECORD

Hodgkinson, lan R., and Paul Hughes. 2019. "A Level Playing Field: Social Inclusion in Public Leisure". figshare. https://hdl.handle.net/2134/14768. 
This item was submitted to Loughborough's Institutional Repository (https://dspace.lboro.ac.uk/) by the author and is made available under the following Creative Commons Licence conditions.

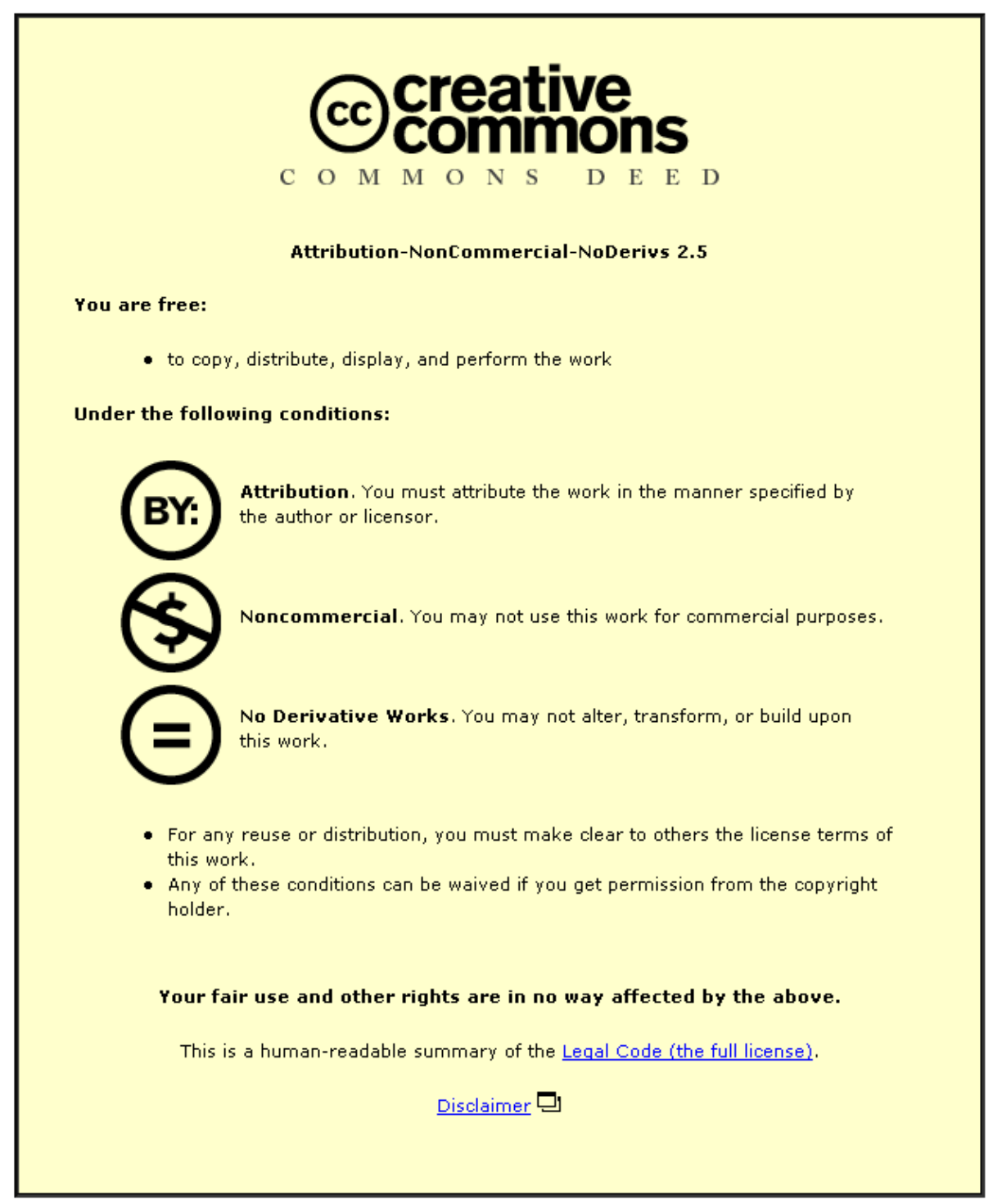

For the full text of this licence, please go to: http://creativecommons.org/licenses/by-nc-nd/2.5/ 


\author{
lan R Hodgkinson \\ Business School \\ Loughborough University \\ Loughborough, UK \\ Paul Hughes \\ Business School \\ Loughborough University \\ Loughborough, UK
}

\begin{abstract}
Purpose - The transfer to partnership in public sector management has created significantly new modes of service delivery and is suggested to be the best means of ensuring that disadvantaged groups are socially included. This research set out to examine New Leisure Trust (NLT) structures in public leisure provision relative to direct, in-house managed facilities and privately run Leisure Management Contractor (LMC) facilities. In particular, NLTs receive significant government funds and subsidies through tax breaks that are not forthcoming to rivals which raise questions as to whether NLTs deserve such aid for delivering upon the social inclusion agenda of the government.
\end{abstract}

Methodology - The research involved a national survey questionnaire to 1,060 public leisure service providers in England. Empirical testing through multiple analysis of variance and regression analysis was applied to the dataset.

Findings - We find that NLTs do not follow social orientation strategies to any significantly greater degree than rivals nor seem to create social inclusion to any greater degree. Further, NLTs have the least to gain in terms of business performance from creating social inclusion whilst in-house (in particular) and LMC facilities stand to gain the most.

Practical implications - Though each approach to provision examined places a considerable strategic emphasis on being socially oriented they are not effective at increasing the social inclusion of recreationally disadvantaged groups.

Originality/value - This paper calls for the current public leisure management playing field to be levelled in a rebalance of opportunity and investment through the removal of anti-competitive measures.

Keywords - partnership, new leisure trusts, public services, social inclusion, performance

Classification - Research Paper 


\section{A Level Playing Field: Social Inclusion in Public Leisure}

\section{Introduction}

A key element of interest in social policy over the last decade has been the provision of, and differential access to, public services (Gorard et al., 2001). New Labour's social inclusion agenda, of which social inclusion objectives emerged as vital mechanisms (Green, 2007), forced many to question how social inclusion can be achieved within a local government environment of funding cuts (Reid, 2003). Simmons (2004) documents the dilemma faced by leisure service managers as to how the balance between financial and social objectives should be struck, which is more relevant than ever given increasing budgetary cuts (Berg et al., 2008). Social inclusion, in this debate, refers to the inclusion of disadvantaged groups in activities that they would otherwise be excluded from (Pavis et al., 2001). Public leisure services have a clear role to play in promoting the well-being of citizens (Liu et al. 2007) and social inclusion is a significant component of this role, seen as enabling disadvantaged groups to gain greater access to health and healthy environments (SEU, 2003). According to Liu et al. (2008) in the context of social inclusion policy, the access of disadvantaged groups to public leisure facilities has been a major concern of local government for a long time, despite the changing modes of service provision.

Traditionally, local government committee boards have overseen public leisure services. Though, increasingly the concept of 'partnership' has become widely promoted as an ideal model for public sector management (Friend, 2006; Peters, 1998) and the policy response to a range of political ills, such as the reduction of inefficiencies in service delivery (Laffin and Liddle, 2006). This is consistent with public management reforms across Europe in an attempt to get public sector organisations to function more effectively (e.g., Turrini et al., 2010). Collaboration between the public, private and voluntary sectors was subsequently promoted under New Labour in leisure service delivery (Diamond, 2006). It is suggested that local government are of the view that high-quality services, delivered by local partnerships characterised by high levels of user and community participation, are the best means of ensuring that disadvantaged groups are socially included (Ellison and Ellison, 2006). This transfer to partnership has created significantly new modes of leisure service delivery yet there is a need to examine and reflect upon the implications these models present (Diamond, 2006). The interest of this research, then, is to investigate social inclusion across different modes of public leisure provision in the context of on-going governmental concerns for social inclusion in an environment of increasing budgetary cuts.

\section{Public Leisure Service Delivery}

Continual restructuring of the public sector has taken place in England over the last twenty years in response to central government policy changes. A central theme underpinning this transformation concerns financial accountability and effectiveness, an emphasis introduced by the Conservative government of the 1980s, which heavily critiqued the welfare state of the past that had focused on the provision of a minimum standard of service to all citizens (Osborne and McClaughlin, 2002). Perceived inefficiency and ineffectiveness in public sector services resulted in privatization (Ascher, 1987) via the introduction of Compulsory Competitive Tendering (CCT). The Competition in Sport and Leisure Facilities Order (1989) marked the introduction of CCT into the realm of local government sport and leisure management and 
contended that local government should not be the sole service provider, implementing a shift towards different vehicles of provision.

In 1997, CCT was replaced by New Labour's policy of Best Value (BV). Similar to $\mathrm{CCT}$, competition is an essential management tool via the use of benchmarking to compare relative performance and the requirement to achieve continuous improvement (Coalter, 2000). As with CCT, under BV, services should not be delivered directly by local government if other more efficient and effective means are available. In sustaining this momentum for change and modernisation, the emphasis on performance measurement has been reinforced by the introduction of Local Public Service Agreements and Comprehensive Performance Assessment (CPA) (Andrews et al., 2005); a performance management framework introduced by the Audit Commission and central government to measure local authority performance (Liu et al., 2007). More recently, the single set of National Indicators (NIS), introduced by Communities and Local Government, is the only set of indicators on which central government performance manage local government services; including those delivered by local government alone and in partnership with other organisations. Such changing political and ideological reforms in the sector underpin a shift in emphasis from securing greater productivity and value for money to partnerships and networks in the delivery of service provision (Ferlie et al., 2003). In response to central government policy changes there are now several management approaches in public leisure service provision. These include hierarchical, market-based, and collaborative approaches to managing service delivery (Martin, 2003). These distinguishable approaches to leisure provision are now addressed.

The in-house management approach to provision (hereafter in-house) is the traditional form of managing public services and still dominates public leisure provision in England (Audit Commission, 2006). In-house provision is hierarchical, with a local government committee board directly monitoring management. Local government takes full responsibility for income, expenditure, pricing and programming, and is accountable for all risks involved. In addition, in-house providers have the smallest marketing budgets of the three approaches to provision to be examined. According to the Audit Commission (2006) this often results in ineffective marketing and missed opportunities to increase income, address the needs of priority groups and improve overall participation. Due to the increasing financial pressures on public leisure services local governments are moving away from in-house provision, towards New Leisure Trust (NLT) or Leisure Management Contractor (LMC) provision.

The trust is a term to describe a range of not-for-profit organisations that may or may not have charitable status (Simmons, 2004). The development of a NLT involves the local government, under the Local government Act (1976), transferring the service and facility to a NLT. This form of management has been a response from local government to a changing environment, particularly in resisting financial pressures resulting from 20 years of government regulation and reform. As the Centre for Public Services (1998) notes, a not-for-profit organisation with charitable status can obtain exemption from VAT on fees and charges, relief on corporation and capital gains tax, and $80 \%-100 \%$ relief on National Non-Domestic Rates. Significantly, however, although these are savings to local government budgets they represent a substantial loss of revenue to the Treasury (Audit Commission, 2006).

In response to competition from NLTs, the private sector now offers partnerships with local government for the management of public leisure facilities. A Public-Private Partnership (PPP) is a somewhat complex arrangement whereby, in exchange for a lengthy management contract, a commercial company invests in the facility that 
provides the service. In turn, local government enters into a performancemanagement contract with a private sector operator, where the private $L M C$ manages the service as an agent of the local government. The financial performance of LMCs is fundamentally stronger than for the other approaches to provision (Audit Commission, 2006). This is largely attributable to a superior level of customer information, achieved through customer profiling, primarily in order to increase income (Audit Commission, 2006), which may carry social implications.

Coalter (1995) notes that much of the academic opposition to the contracting out of public leisure services concerns the presumed shift from welfarism to entrepreneurialism, with an associated decline in the willingness of public leisure services to cater to disadvantaged groups. However, Liu et al. (2009) present evidence to counter this argument, which suggests that commercial contractors (i.e., LMCs) outperform significantly both in-house and NLT facilities across a number of social performance indicators. This provides an interesting avenue to investigate, since the Audit Commission (2006) suggest that a large proportion of LMC marketing is focused exclusively on higher-income groups, which could be assumed to run counter to social objectives.

\section{Public Leisure Provision and Recreational Welfare}

Social inclusion is the policy or act of overcoming barriers such that people have more opportunity to take part (Collins, 2004). Social inclusion became a major policy objective of the British government from 1997 (Liu et al., 2009) and has been a strong tradition in UK local government leisure provision, which has focused on the promotion of equal opportunity for participation (Liu, 2009). The significance of social inclusion and leisure provision to both central and local government is expressed by Collins (2004: 62), who states: "If in the modern world, access to sport, physical activity and culture are part of the citizen's package of expectations, or even, by some people's values, of citizen's rights, then this is a social policy issue for the state both centrally and locally". This is highlighted by the growing significance of sport policy interventions that have sought to promote inclusion in sport and leisure, examples include A Sporting Future for All, Game Plan, Sport Playing its Part, and Every Child Matters (cf. Green, 2007). Social inclusion, then, represents a key rationale for public leisure provision, that is, a concern with recreational welfare and the targeting of provision for recreationally disadvantaged groups (Coalter et al., 1986). Public leisure facilities are provided by local government on the basis of equal opportunity or presumed associated benefits (Liu, 2009). Participation in sport and leisure, for example, is suggested to be beneficial to society (Collins, 2004; Gratton and Taylor, 2000), with the potential to improve health and reduce crime (Audit Commission, 2006). These social objectives have traditionally provided the justification for the provision and subsidy of public sport and leisure services (Robinson, 2004). More recently, the initiative to pursue social inclusion has been a direct expression of government intervention on the grounds of equity (Liu et al., 2009). Equity in this context "...implies that the unequal should be treated unequally and involves allocating services so that economically disadvantaged groups receive extra increments of resources" (Liu et al., 2009: 5).

Pavis et al. (2001) identify this redistributive discourse in British social policy. Here, it is argued that some groups of people lack the material resources necessary to participate in activities, which are available to the rest of society. Therefore, public leisure facilities are provided at subsidised prices by local government (Liu, 2009). However, large differences remain in participation as measured by social groups 
(Collins, 2008). In addition, there is a degree of variation in the financial operation of the approaches to provision identified, which if accounted for, may influence the participation of social groups. For example, redistributive objectives in the name of fairness, social justice and solidarity can arguably enable not-for-profit organisations, such as NLTs, access to additional central government financial assistance in support of disadvantaged groups. In-house provision receives considerably more local government subsidy for the operation of leisure facilities, relative to NLT or LMC approaches. While LMCs are afforded flexibility by local government on membership prices in order to provide opportunities to increase income (Audit Commission, 2006). Hence, the adoption of different approaches to service provision may carry social inclusion (exclusion) implications.

The heritage of charitable NLTs lies in the creative defence of public services (Simmons, 2004), providing an opportunity to preserve the social welfare of service delivery in response to the assumed shift towards the commercialisation of leisure services, through contracting with the private sector (i.e. LMC). NLTs are therefore claimed to offer the greatest opportunities for community benefit, providing local government with an opportunity to establish the welfare objectives of leisure services (Simmons, 2004) while resisting the budgetary pressures faced by direct in-house public leisure provision. The Audit Commission (2006), however, has suggested on the basis of its independent research that no single approach to provision consistently results in more investment or higher levels of participation. There has been a significant acknowledgement of this knowledge gap in the literature in recent times, particularly in relation to social inclusion of public leisure facilities (e.g., Liu, 2009; Liu et al., 2009, 2008, 2007). It remains vital, however, to broaden the analysis of social inclusion in public leisure services to account for the social orientation of public leisure providers, relative to each approach to provision, and the need for leisure services to simultaneously realise social objectives and secure economic survival through business performance, during a time of increasing budgetary cuts (Berg et al., 2008).

This study has three aims, first, to carry out an investigation of significant variations in the degree of strategic social orientation among the three approaches to managing public leisure provision. It has been identified that the opposition to the externalisation of leisure services lies in the concern for recreational welfare. Social inclusion should, however, be a strategic concern regardless of management approach, since the rationale for public leisure services is the promotion of recreational welfare. Second, in examining the degree of inclusion of recreationally disadvantaged groups, within facilities across management approaches, an attempt is made to develop existing understanding of the success of leisure services in achieving central government-governed social objectives. Third, an empirical examination of significant relationships between social inclusion and business performance in public leisure provision will identify whether social inclusion is viable for public leisure facilities given an environment of increasing budgetary cuts (Berg et al., 2008).

\section{Hypotheses}

For the purposes of hypothesising, we define a strategic social orientation as the reduction of inequalities between the least advantaged groups and communities and the rest of society. Whereby, the public leisure facility seeks to include all citizens, achieved through targeted programming. Social inclusion, as previously stated refers to the inclusion of disadvantaged groups in leisure activities that they would 
otherwise be excluded from. As noted, the reformed local government sector in England uses a variety of approaches in public leisure provision embodying different degrees of collaboration and private involvement. We focus on in-house, NLTs and LMCs as the three primary approaches to public leisure provision.

\subsection{Strategic Social Orientation and Social Inclusion}

The ethos of recreational welfare forms the basis for the charitable status that is granted to NLTs on the grounds of 'community benefit' (Reid, 2003). The soft budget constraint afforded to NLTs is related to redistributive policies that support disadvantaged groups, enabling NLTs access to additional financial assistance, provided by the state. This allows traditional financial pressures to be eased, subsequently resulting in the promotion of social objectives. Consequently, it would be expected that trusts would promote social inclusion and pursue socially oriented strategies. The rationale for state provision is to ensure access for all citizens to sport and leisure opportunities achieved through targeted programming (Robinson, 2004). This implies that, similar to NLTs, in-house provision may be biased towards a social orientation and increased inclusion, as local government oversee the operational management of such facilities. Consequently, in-house providers receive a considerably higher level of local government subsidy, relative to NLTs and LMCs (Audit Commission, 2006), and are therefore expected to promote equity in leisure provision.

LMCs, on the other hand, receive limited financial support from local government in the operational management of public leisure facilities. Therefore, LMCs are dependent upon the generation of revenue for their continued survival. Subsequently, as Simmons (2004) identifies, reduced priority is given to the promotion of social objectives as it is assumed that such objectives would run in conflict to the operational survival of such facilities. Further, LMCs tend to focus on high-income groups in pursuit of profit maximisation (e.g., Audit Commission, 2006), since a profit maximising creditor would only be concerned for the return on projects and not for community benefit (Dewatripont et al., 1999). As evidence, LMCs have far superior revenue generation relative to in-house and NLT facilities (Mintel, 2006). LMCs are, then, less likely to pursue socially oriented strategies and be less concerned with social inclusion relative to rivals.

Overall, we expect NLTs and in-house facilities to emphasise social orientation in their strategies and be focused upon delivering high levels of social inclusion. As such, these management arrangements should be more socially oriented and create far greater levels of social inclusion than their LMC rivals.

$\mathrm{H}_{1}$ : Strategic social orientation will be emphasised to a greater degree by NLTs and in-house management than LMC managed public leisure facilities.

$\mathrm{H}_{2}$ : Social inclusion will be greater in NLT and in-house managed public leisure facilities than LMC managed public leisure facilities.

\subsection{Social Inclusion and Business Performance}

In the UK, local government leisure services are facing a serious funding problem (Liu et al., 2008). A typical reaction by firms to recession or financial pressures is to cut costs (e.g. Frohlich and Dixon, 2001). This is likely to be particularly the case for LMCs who receive the lowest subsidies of the three approaches identified (Audit Commission, 2006). Thus, unless social objectives are specified in contract specifications by local government then the pressure is there for LMCs to increase 
income by targeting those customers with greater financial resources (Bailey and Reid, 1994), that is, the higher-income groups. As evidence, the Audit Commission (2006) cite that in $80 \%$ of cases, LMC marketing was focused exclusively on higherincome groups.

LMCs are suggested to concentrate on the higher-income groups due to the fact that they are profit-making entities and sources of investment come from redistributing profit. Consequently, in order to provide higher customer value and attract more custom from higher-income groups, these companies need to make profits in order to reinvest in the service to refurbish and replace old facilities (Mintel, 2006). It would appear counterproductive for LMCs to pursue social inclusion, beyond specified social objectives in a service contract, as disadvantaged or low-income groups generally cannot participate in the relatively high cost service offered by LMCs (vis-àvis leisure facilities managed by subsidised NLTs or local authority in-house run facilities). As such, we would expect that LMCs that redistribute profit into social inclusion would in fact suffer from negative performance due to the lower likelihood of returns on the investment in recreationally disadvantaged groups.

In contrast both in-house and NLT managed facilities receive a greater degree of financial subsidy either directly or indirectly from local government, subsequently such approaches are expected to increase the inclusion of low-income groups. It is anticipated that in-house managed facilities and NLTs would benefit significantly in performance terms from attempts to entice recreationally disadvantaged and lowincome groups into using their facilities. This is partly due to the financial subsidies they entail but also due to the fact that higher-income groups are unlikely to be enticed by their value offerings relative to the multitude of facilities and modern equipment typically offered by LMCs (e.g., Audit Commission, 2006).

Ultimately, social inclusion in terms of attracting disadvantaged low-income groups to use leisure facilities is likely to be of benefit to in-house and NLT facilities. However, due to the nature of LMCs in pursuing high-income groups, LMCs are not likely to benefit from the costs incurred in attracting these groups.

$\mathrm{H}_{3}$ : Social inclusion will be positively associated with business performance for NLT public leisure provision.

$\mathrm{H}_{4}$ : Social inclusion will be positively associated with business performance for in-house public leisure provision.

$\mathrm{H}_{5}$ : Social inclusion will be negatively associated with business performance for LMC public leisure provision.

\section{Research Method}

\subsection{Data Generation}

In this study a public leisure service refers to a publicly-owned site, with at least one of the following facilities; health \& fitness suite, swimming pool or sports hall, where at least one is available to members of the general public on a pay and play or membership basis. Using a mail survey approach, 1,060 questionnaires were sent to public leisure facility managers nationally. 280 replies were subsequently received forming an overall response rate of $26 \%$. A substantial representation of all three approaches to provision was achieved. Specifically, $28 \%$ of the total population of inhouse (152), $26 \%$ of NLT (75), and $23 \%$ of private LMC (53) public leisure facilities 
participated in the study. Public leisure facility managers were deemed key informants because such individuals have the knowledge necessary to provide accurate information and data on the strategic orientation and business performance of the facilities examined. Moreover, they are responsible for implementing strategic actions to achieve desired performance outcomes and may be assumed to be a key factor in achieving such outcomes between the three approaches to provision identified. Identifying the facility level manager as a key informant is also consistent with previous research examining the strategic characteristics of sport and recreation provision (e.g., Benson and Henderson, 2005). This study does not account for the broader strategy formation process, which would involve local management boards (in-house), trustees (NLTs), and executive boards (LMCs), as this was beyond the scope of the study. The survey instrument follows the recommendations, directions and principles of good questionnaire development practice as set forth by Dillman (2007).

\subsection{Measures Employed}

Based upon discussions with local government councillors and leisure managers, this study used five short unlabelled paragraphs that depicted a variety of strategic orientations. In adopting the self-typing paragraph descriptor approach, facility managers characterised the realised strategies of the leisure facilities being examined. This measurement instrument was employed to identify significant variations in the degree of strategic social orientation among the three approaches to managing public leisure provision. James and Hatten (1995) consider this measurement instrument to be logically appealing and effective since top managers' perceptions largely define strategy. Strategic orientations were ranked using a 7point Likert-type scoring.

Social performance was gauged by the degree of social inclusion achieved by the leisure facilities examined, using objective individual facility usage records derived from the National Fitness Audit (2007). Here, social inclusion is calculated on the basis of the postcode distribution of a facility's usage compared with the postcode analysis of the population in the facility's catchment area (defined as a three mile radius). This is similar to the socio-economic profile of facility catchment used in the National Benchmarking Service for sports halls and swimming pools (NBS) developed by the Sport Industry Research Centre (Liu, 2009), which employs a fifteen-minute drive-time facility catchment area. To benchmark participation, then, analysis of facility usage data can be compared with catchment demographics. We utilise Experian's demographic classification system, Mosaic (the leisure industry standard in consumer segmentation systems), to ascertain the percentage of target groups who are using the facility within the given facility catchment area. The Mosaic tool from Experian is appropriate for the purpose of this study given that we do not seek to identify what performance is like relative to national benchmarks (e.g., Liu et al., 2007). Rather, we seek to identify comparisons between the three approaches to provision identified. Moreover, the legitimacy of the tool used is established on the basis that Sport England use Mosaic classification to inform its own market segmentation research and the tool has been previously applied to leisure and recreation contexts (e.g., Doward, 2009). The focus here is on the participation of recreationally disadvantaged groups, which we define as welfare borderline, municipal dependency and twilight subsistence using the parameters of the Mosaic classification system. These specific groups are considered recreationally disadvantaged based on an identified exclusion to leisure opportunities of lower socio-economic groups (Audit commission, 2006) and exclusion among older people (Liu, 2009). 
Business performance encompasses perceptual measures regarding new customers, marketing, profitability, and market share. The items adopted place emphasis on financial performance, specifically new customer sales, profitability, market share and marketing, which refers to the ability to refine facility activities now and into the future which can generate significant benefits in the form of sustainably superior performance (Lichtenthaler, 2009; Cockburn et al., 2000). Therefore, since the items focus on economic outcomes (Delaney and Huselid, 1996) it was deemed appropriate to combine the four measures into a single dependent variable termed business performance. To gauge the degree of internal consistency of the business performance scale, Nunnally's (1978) threshold of .70 or greater for acceptable scale reliability is adopted in interpreting the Cronbach alpha coefficients. Since the business performance scale displays acceptable levels of reliability (.82), it can be concluded that internal consistency exists among the business performance variables that comprise the said scale. Research has found measures of perceived organisational performance to correlate positively with objective measures of organisational performance (Krohmer et al., 2002; Delaney and Huselid, 1996). In addition, the inclusion of perceptual measures enables an analysis of business performance of public organisations, which include both for-profit and not-for-profit organisations, as objective data for the latter is generally unavailable (Krohmer et al., 2002). The 7-point Likert-type scoring was adopted for business performance items.

In distributing the questionnaire to several public leisure managers, with the objective to ensure that the measures employed were appropriately worded and understood by the respondents, face validity was accounted for. To ensure the accuracy of responses, feedback given by public leisure managers on the measures employed was used to enhance and modify the research questionnaire. Given that a mix of subjective (strategic orientation and business performance) and objective (social inclusion) data is used, common method bias is not of concern in this study.

\section{Analysis and Results}

Correlation analysis is utilised as a means to confirm the validity of the research hypotheses. The purpose of this analysis is to provide an early indication of the kind of association between study variables and in turn, to develop an understanding of the relationship characteristics between study variables. Table 1 presents the results of the correlation analysis.

\begin{tabular}{l|c|c|c}
\hline \multicolumn{3}{c}{ Table 1: Correlation Matrix and Descriptive Statistics } \\
\hline 1 Social Orientation & 1 & 2 & 3 \\
2 Social Inclusion & -.16 & & \\
3 Business Performance & -.03 & $.41^{\star \star}$ & \\
\hline Mean & 5.47 & 1.80 & 4.69 \\
SD & 1.51 & 1.77 & 1.05 \\
\hline
\end{tabular}

Notes: **. Correlation is significant at the 0.01 level (2-tailed).

The analysis demonstrates a significant positive relationship between social inclusion and business performance. However, there appears to be no significant relationship between social orientation and either actual inclusion or business performance. Correlation analysis is employed as a precursor to more extensive hypothesis testing through multivariate analysis of variance and multiple regression analysis.

Multivariate analysis of variance was performed to test hypotheses $\mathrm{H} 1$ that NLTs and in-house facilities will be more socially oriented than LMCs and H2 that NLTs and in- 
house facilities would also exhibit far greater levels of social inclusion relative to their LMC rivals. The results of the multivariate analysis of variance and the findings of the Scheffé procedure for social orientation and social inclusion are presented in Table 2. Since the concern is to establish whether significant differences exist between the groups, the Scheffé test is utilised to identify comparisons among groups that have significant differences.

\begin{tabular}{c|c|c|c|l|l}
\hline \multicolumn{6}{c}{ Table 2: MANOVA Analysis of Strategic Social Orientation and Social } \\
Inclusion
\end{tabular}

NSD: no significant differences found.

The ethos of recreational welfare and social inclusion forms the basis for the charitable status of the majority of NLTs, granted on the grounds of 'community benefit', and the purpose of provision for in-house managed facilities. However, it could be argued on the basis of the results presented in Table 2 that in practice, LMC managed facilities place the same strategic emphasis on social orientation as NLT and in-house provision, despite the substantial difference in the allocation of state subsidies. This is demonstrated by the proximity of the mean values presented (inhouse, 5.51; NLT, 5.48; LMC, 5.33) and the absence of any significant differences among the groups. Since no significant differences are found between the three groups it is clear that $\mathrm{H} 1$ is not supported. NLTs and in-house provision do not place significantly greater emphasis on social orientation in strategy in comparison with LMCs.

As observed in Table 2, regarding the specific inclusion of recreationally disadvantaged groups, NLT and LMC leisure provision exhibit similar mean values of 2.25 and 2.02 respectively. In-house leisure provision, on the other hand, exhibits a mean value of 1.19 , which is substantially lower than the other two groups. This indicates that of the three approaches to provision, in-house facilities are least effective in creating social inclusion currently, on the basis of the mean values presented. The Scheffé test, however, does not identify any significant differences among the management approaches when examined against achieved inclusion of recreationally disadvantaged groups, providing no support for $\mathrm{H} 2$.

The results thus far have established that no single approach to provision significantly follows a social orientation or creates greater social inclusion than any other. However, creating social inclusion may lead to greater custom and opportunities for enhanced profit and business performance. Therefore, we hypothesised that social inclusion would have performance implications $(\mathrm{H} 3, \mathrm{H} 4$ and $\mathrm{H} 5$ ). Thus, in addition to the multivariate analysis of variance, standard multiple regression analysis (the method of least squares) is applied to assess the relationship between social inclusion and business performance for each approach to provision.

Table 3: Regression Model of the Relationship Between Social Inclusion and Business Performance

\begin{tabular}{|c|c|c|c|c|}
\hline $\begin{array}{l}\text { Management } \\
\text { Approach }\end{array}$ & $\begin{array}{c}\text { Independen } \\
\text { Variable }\end{array}$ & $\mathbf{H}$ & $\begin{array}{l}\text { Regression } \\
\text { Coefficient }\end{array}$ & $\begin{array}{l}\text { Standardised } \\
\text { Regression }\end{array}$ \\
\hline
\end{tabular}




\begin{tabular}{|c|c|c|c|c|c|}
\hline & & & & Coefficient & \\
\hline NLT & $\begin{array}{c}\text { Social } \\
\text { Inclusion }\end{array}$ & H3 & .09 & .16 & 65 \\
\hline In-house & $\begin{array}{c}\text { Social } \\
\text { Inclusion }\end{array}$ & $\mathrm{H} 4$ & .33 & .62 & $3.27^{\text {** }}$ \\
\hline \multirow[t]{3}{*}{ LMC } & $\begin{array}{c}\text { Social } \\
\text { Inclusion }\end{array}$ & H5 & .27 & .46 & $2.03 \dagger$ \\
\hline & & del Statistics & & & \\
\hline & $R^{2}$ & Adjusted $R^{2}$ & $F$-value & & \\
\hline NLT & .03 & -.04 & .42 & & \\
\hline In-house & .39 & .33 & $10.66^{\star \star}$ & & \\
\hline LMC & .22 & .16 & $4.11 \dagger$ & & \\
\hline
\end{tabular}

Notes: ${ }^{*} p \leq 0.01 ; \dagger p \leq 0.1$

Table 3 presents the regression results pertaining to the dependent variable business performance with social inclusion as the independent variable. The regression analysis tested the hypotheses that actual social inclusion will have a positive association with business performance for NLTs and in-house managed facilities, whilst delivering negative performance implications for LMCs. In considering social inclusion of recreationally disadvantaged groups for NLTs, no significant relationship is found for an effect on performance by social inclusion. Further revelations are provided by the model statistics which show social inclusion accounts for only $3 \%$ of NLT performance. $\mathrm{H} 3$ then is not supported. The story however differs significantly for in-house and LMC managed facilities. Social inclusion confers significantly positive performance benefits for in-house leisure facilities $(.62, p \leq .01)$ and explains $39 \%$ of in-house facility business performance. Not only does this support $\mathrm{H} 4$ but confirms that in-house facilities stand to gain the most from pursuing a social inclusion agenda. Perhaps most surprisingly, from a theoretical and literature point of view is the power of social inclusion in conferring positive performance benefits for LMCs $(.46, p \leq .1)$, thus refuting $\mathrm{H} 5$. Clearly these results have a number of significant implications.

\section{Discussion}

This research sought to examine empirically whether there were significant variations between NLT, in-house and LMC provision in pursuing social orientations in strategy and social inclusion, and whether social inclusion is viable for public leisure facilities by determining its effect on business performance. In sum, we find that there is no significant variation in the social orientation of the three approaches to provision, moreover, no significant difference is found when considering the degree of social inclusion achieved. Despite the perceived inclusiveness of NLT provision, this has the least to gain in terms of business performance from creating social inclusion whilst in-house, in particular, and LMC facilities stand to gain the most. In considering the context of recent government changes, which have seen the implementation of budget cuts (Berg et al., 2008), there is increased priority for leisure services to generate revenue. The findings suggest that business performance can be realised by increasing inclusion within in-house and LMC provision.

Contractors argue that current public sector leisure delivery is anti-competitive, preventing them from being able to demonstrate how they can improve utilisation of facilities while reducing local government subsidies (Mintel, 2006). The financial benefits enjoyed by NLTs are provided on the basis that they perform to governmental expectations of improving social inclusion (MacVicar and Ogden, 
2001). Each approach to provision examined places a considerable strategic emphasis on being socially oriented (on the basis of the mean values presented in Table 2), which may be expected in light of central government pressure. When compared against actual achieved inclusion, it becomes evident that those same approaches to provision are equally effective at increasing the inclusion of recreationally disadvantaged groups, despite having different governance and funding structures. Given that a strategic social orientation and social inclusion is not significantly emphasised to any greater degree by NLTs, than LMC or in-house provision, we suggest that government policy must be rethought. More specifically, redistributive objectives in the name of fairness, social justice and solidarity enable NLTs access to additional financial assistance, in support of disadvantaged groups; however, such objectives appear to be ineffective in the case of leisure provision. The fundamental point arising from our findings is the need to re-examine public policy on how social inclusion is delivered in leisure provision.

However, the adoption of NLT provision by local governments may go beyond a general concern for social inclusion, since the Audit Commission (2006) cite that in a number of cases local government appear to have established NLTs primarily to make savings and in some instances, have done so without consideration of service improvements or thought of reinvestment. The subsequent reduction of subsidies by host councils, in the transfer of management to a NLT can consequently increase financial pressures on such facilities if the savings made are not reinvested into the facilities. Hence, the Audit Commission (2006) suggest that some NLTs are forced to concentrate on profit-oriented activities in order to establish financial stability, thus reducing their focus on recreational welfare and undermining their social purpose. If no business performance benefits are forthcoming to NLTs in pursuit of social inclusion then the management of such facilities have little choice other than to focus on profit-oriented activities to secure the operational survival of those facilities. This clearly runs counter to the whole ethos behind their use. Given the benefits of reduced taxation and so forth enjoyed by NLTs, government policy that directs NLTs to increase inclusion amongst specific recreationally disadvantaged groups, can be considered ineffective. If NLT provision is to remain a part of the social inclusion agenda then it may well be time to scale back on subsidies before their individual social effectiveness can be established. We concur with Diamond (2006) that a 'fitness for purpose' test is an appropriate way forward here. Otherwise, it is time for central government to rethink its policies on forcing collaboration between public, private and voluntary sectors (Diamond, 2006) and seek to understand the most effective way forward to modernise social leisure provision.

Public leisure providers can be said to have a dual strategic agenda, since they face the same economic pressures to survive as private organisations (Clohesy, 2003), but have a social duty to effectively deliver a range of services to nominated consumer groups (Perrott, 1996), that is, the recreationally disadvantaged. We advocate changes in government policy to level the playing field and redistribute financial resources to create an economically sustainable means of realising social inclusion in public leisure provision. Our results provide two possible alternatives for this to be realised. Firstly, by redistributing finance towards in-house provision for social purposes in the short-term, in-house provision may realise revenue generation in the long-term based on the significant positive relationship between social inclusion and in-house business performance. Secondly, LMC provision may enable local government to deliver on social inclusion in leisure provision in an uncertain funding environment, since LMCs require the lowest subsidy from local government relative to NLT and in-house provision (Audit Commission, 2006). We suggest that contractors are incentivised to increase inclusion, not just on the basis of contract 
specifications, but because social inclusion has been found to benefit the business performance of such providers enabling further reinvestment opportunities.

\section{Limitations and Directions for Future Research}

This study was not without its limitations. First, this research study was based on a cross-sectional design, which suffers from the same limitations as all cross-sectional research designs in not allowing causality to be asserted from the data. Second, we sampled public leisure facilities in England. As government structures, service delivery, and resource allocation systems differ between industries and countries we caution against generalising our results to populations markedly different to that examined here. Third, we did not have access to social inclusion data for the whole sample and only assessed it via one method (using objective individual facility usage records). Fourth, perceptual measures of business performance are relied upon as access to objective business performance data was largely unavailable and thus could not be employed. We acknowledge this as a limitation. Fifth, judgements about social orientation and business performance, although qualified, have been reported by a single informant and may not sufficiently capture the multi-faceted aspect of these constructs. Sixth, the regression model for NLTs exhibits a relatively weak Adjusted $R^{2}$ and $F$-value which suggests that other influencing variables are present, this in turn restricts the relative confidence by which assertive findings and conclusions may be drawn. Finally, social orientation is captured by a single item measure, which the authors acknowledge is less reliable than a multiple-item measure.

We note several directions for future research. The first would serve to enhance the quantitative findings of this study and surrounds the need to investigate what does help in increasing social inclusion in public leisure provision. This would allow the issue of social inclusion to be examined in greater depth and may uncover means by which social inclusion within public leisure provision can be increased. It is suggested that such research would enhance the practicability of the study findings for public leisure managers. A second direction for future research is to investigate deeper the governmental implications of public leisure management. Considering that local government retain ownership of public facilities, despite the management approach adopted, it would be valuable to investigate whether performance outcomes ultimately influence local government decision-making in the management approach selected for the delivery of public services. The concern here is with future service delivery in light of the social performance outcomes of the management approaches examined. Third, Hart and Haughton (2007) indicate that it is possible to assess the 'value added' of social enterprises, hence NLTs. We argue that this is vital now more than ever to determine what value NLTs add given their significant financial incentives and subsidies but lack of delivering on social inclusion.

\section{References}

Andrews, R., Boyne, G.A., Law, J. and Walker, R.M. (2005), "External constraints on local service standards: the case of comprehensive performance assessment in English local government", Public Administration, Vol. 83 No. 3, pp. 639-656.

Ascher, K. (1987), The politics of privatization, Macmillan, London. 
Audit Commission (2006), Public sports and recreation services: making them fit for the future, Audit Commission for Local Authorities and the National Health Service in England: Local Government National Report, June.

Bailey, S. and Reid, G. (1994), "Contracting municipal sports management: policymaking interactions", Local Government Policy-Making, Vol. 21 No. 2, pp. 55-66.

Benson, A.M. and Henderson, S. (2005), "Strategic characteristics of sport and recreation provision: an application of SPACE analysis", Managing Leisure, Vol. 10 No. 4, pp. 251-267.

Berg, E.B., Barry, J.J. and Chandler, J.P. (2008), "New public management and social work in Sweden and England", International Journal of Sociology and Social Policy, Vol. 28 No. 3/4, pp. 114-128.

Centre for Public Services (1998), Leisure and Library Trusts, UNISON: London.

Clohesy, W.W. (2003), "Fund-raising and the articulation of common goods", Nonprofit and Voluntary Sector Quarterly, Vol. 32 No. 1, pp. 128-140.

Coalter, F. (2000), "Public and commercial leisure provision: active citizens and passive consumers?", Leisure Studies, Vol. 19 No. 3, pp. 163-181.

Coalter, F. (1995), "Compulsory competitive tendering for sport and leisure management: a lost opportunity?", Managing Leisure, Vol. 1 No. 1, pp. 3-15.

Coalter, F., Long, J. and Duffield, G. (1986), Rationale for public sector investment in leisure, Sports Council/ESRC, London.

Cockburn, I., Henderson, R. and Stern, S. (2000), "Untangling the origins of competitive advantage", Strategic Management Journal, Vol. 21 (Special Issue), pp. 1123-1146.

Collins, M.F. (2008), "Social exclusion from sport and leisure", in Houlihan, B. (Ed.), Sport and Society, Sage, London, pp. 77-105.

Collins, M.F. (2004), "Driving up participation: social inclusion", in Sport England (Ed.) Driving Up Participation: The Challenge for Sport, London, pp. 61-67.

Delaney, J.T. and Huselid, M.A. (1996), "The impact of human resource management practices on perceptions of organisational performance", Academy of Management Journal, Vol. 39 No. 4, pp. 949-969.

Dewatripont, M., Maskin, E. and Roland, G. (1999), "Soft budget constraints and transition", in Maskin, E. and Simonovits, A. (Eds.), Planning, shortage and transformation: essays in honor of janos kornai, MIT Press, Cambridge.

Diamond, J. (2006), "Au revoir to partnerships: what's next?", International Journal of Public Sector Management, Vol. 19 No. 3, pp. 278-286.

Dillman, D.A. (2007), Mail and internet surveys: the tailored design method, John Wiley \& Sons: New Jersey.

Doward, J. (2009), "Wealthy elderly turn backs on seaside havens", The Observer, 26 July, pg. 12. 
Ellison, N. and Ellison, S. (2006), "Creating 'opportunity for all'? new labour, new localism and the opportunity society", Social Policy and Society, Vol. 5 No. 3, pp. 337-348.

Ferlie, E., Hartley, J. and Martin, S. (2003), "Changing public service organizations: current perspectives and future prospects", British Journal of Management, Vol. 14 No. 1 , pp. 1-14.

Friend, J. (2006), "Partnership meets politics: managing within the maze", International Journal of Public Sector Management, Vol. 19 No. 3, pp. 261-277.

Frohlich, M.T. and Dixon, J.R. (2001), "A taxonomy of manufacturing strategies revisited", Journal of Operations Management, Vol. 19 No. 5, pp. 541-558.

Gorard, S., Taylor, C. and Fits, J. (2001), "Social exclusion and public policy: the relationship between local school admission arrangement and segregation by poverty", International Journal of Sociology and Social Policy, Vol. 21 No. 4/5/6, pp. 10-36.

Gratton, C. and Taylor, P. (2000), The economics of sport and recreation, E\&FN Spon, London.

Green, M. (2007), "Governing under advanced liberalism: sport policy and the social investment state", Policy Sciences, Vol. 40 No. 1, pp. 55-71.

Hart, T. and Haughton, G. (2007), Assessing the economic and social impacts of social enterprise, Cabinet Office, London.

James, W.L. and Hatten, K.J. (1995), "Further evidence on the validity of the self typing paragraph approach: Miles and Snow strategic archetypes in banking", Strategic Management Journal, Vol. 16 No. 2, pp. 161-168.

Laffin, M. and Liddle, J. (2006), "New perspectives on partnership", International Journal of Public Sector Management, Vol. 19 No. 3, editorial.

Lichtenthaler, I. (2009), "Absorptive capacity, environmental turbulence, and the complementarity of organisational learning processes", Academy of Management Journal, Vol. 52 No. 4, pp. 822-846.

Liu, Y.D. (2009), "Sport and social inclusion: evidence from the performance of public leisure facilities", Social Indicators Research, Vol. 90 No. 2, pp. 325-337.

Liu, Y.D., Taylor, P. and Shibli, S. (2009), "Sport equity: benchmarking the performance of english public sport facilities", European Sport Management Quarterly, Vol. 9 No. 1, pp. 3-21.

Liu, Y.D., Taylor, P. and Shibli, S. (2008), "Utlizing importance data to identify customer segments for English public sport facilities", Managing Leisure, Vol. 13 No. 3, pp. 189-206.

Liu, Y.D., Taylor, P. and Shibli, S. (2007), "The operational efficiency of English public sport facilities", Managing Leisure, Vol. 12 No. 4, pp. 251-272. 
MacVicar, A. and Ogden, S.M. (2001), "Flexible Working in Sport and Recreation: Current Practices in Scottish Public, Not-For-Profit and Private Leisure Facilities", Managing Leisure, Vol. 6 No. 3, pp. 125-140.

Martin, S. (2003), "On public management reform", British Journal of Management , Vol. 14 No. 1, pp. 79-81.

Mintel (2006), Leisure centres and swimming pools - UK: leisure intelligence, Mintel International Group Limited, London

Nunnally, J.C. (1978), Psychometric Theory, McGraw-Hill, New York, NY.

Osborne, S.P. and MCLaughlin, K. (2002), "The new public management in context", in MClaughlin, K., Osborne, S.P. and Ferlie, E. (Eds.), New public management: current trends and future prospects, Routledge, London, pp. 7-14.

Pavis, S., Hubbard, G. and Platt, S. (2001), "Young people in rural areas: socially excluded or not?", Work, Employment \& Society, Vol. 15 No. 2, pp. 291-309.

Perrott, B. (1996), "Managing strategic issues in the public service", Long Range Planning, Vol. 29 No. 3, pp. 337-345.

Peters, B. (1998), "With a little help from our friends: public-private partnerships as institutions and instruments", in Pierre, J. (Ed.), Partnerships in Urban Governance, Macmillan, London, pp. 1-10.

Reid, G. (2003), "Charitable trusts: municipal leisure's third way?", Managing Leisure, Vol. 8 No. 4, pp. 171-183.

Robinson, L. (2004), Managing public sport and leisure services, Routledge, London.

SEU (2003), United Kingdom national action plan on social exclusion, SEU, London.

Simmons, R. (2004), "A trend to trust? the rise of new leisure trusts in the UK", Managing Leisure, Vol. 9 No. 3, pp. 159-177.

Simmons, R. (2008), "Harnessing social enterprise for local public services: the case of new leisure trusts in the UK", Public Policy and Administration, Vol. 23 No. 3, pp. 278-301.

Turrini, A., Cristofoli, D., Nasi, G. and Soscia, I. (2010), "Lifting the veil of Maya: measuring the implementation gap of public management reforms in Italy", International Journal of Public Sector Management, Vol. 23 No. 1, pp. 5-21.

Wallis, L. (1999), "Fit for a king", Guardian Society, 28 April, pg. 8. 